\title{
Coal and Petroleum Resources in the Appalachian Basin-Index Maps of Included Studies
}

By Leslie F. Ruppert, Michael H. Trippi, and Scott A. Kinney

Chapter B.1 of

Coal and Petroleum Resources in the Appalachian Basin:

Distribution, Geologic Framework, and Geochemical Character

Edited by Leslie F. Ruppert and Robert T. Ryder

Professional Paper 1708 
Suggested citation:

Ruppert, L.F., Trippi, M.H., and Kinney, S.A., 2014, Coal and petroleum resources in the Appalachian basin-Index maps of included studies, chap. B.1 of Ruppert, L.F., and Ryder, R.T., eds., Coal and petroleum resources in the Appalachian basin; Distribution, geologic framework, and geochemical character: U.S. Geological Survey Professional Paper 1708, 37 p., http://dx.doi.org/10.3133/pp1708B.1. 


\section{Contents}

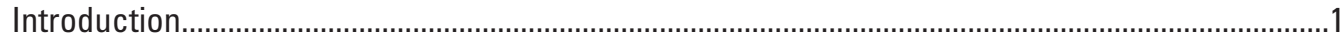

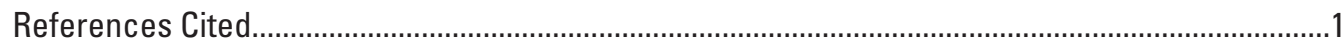

\section{Figures}

1-17 Index maps of the Appalachian basin resource framework study area showing-

1. The difference between the study area outline and the boundary of the Appalachian Basin Province (Province 67) .................................................................5

2. State and county boundaries within the study area ...............................................

3. Oil and gas production in the Appalachian basin and the coal-bearing

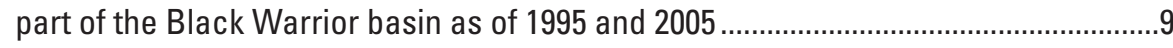

4. The locations of oil and gas fields in Upper Devonian sandstone reservoirs..................13

5. The locations of the northern, central, and southern Appalachian coal regions, coal fields, and the Pennsylvania Anthracite region ......................................15

6. Cumulative production of bituminous coal by county for the years 1899 through 2003

7. The locations of 10 cross sections of regional extent through the subsurface of the Appalachian basin

8. Conodont color alteration index (CAI) sample locations and interpreted isograds for Ordovician rocks

9. Sample locations and interpreted isograds for percent vitrinite

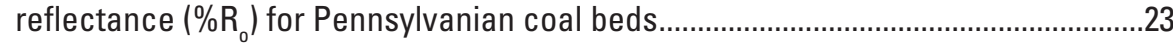

10. The locations of coalbed-methane (CBM) assessment units......................................25

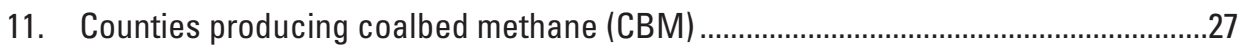

12. Potential sulfur dioxide emissions from combustion of coal delivered to powerplants from coal-producing counties for the years 1996 through 2005 ...........29

13. The locations of wells in Geauga and Trumbull Counties, Ohio, and Mercer and Butler Counties, Pennsylvania, where oil and gas were sampled in Lower Silurian reservoirs

14. The locations of the Conasauga-Rome/Conasauga Total Petroleum System and of selected wells in the Rome trough that had oil and gas production and shows

15. The locations of samples from Silurian reservoirs in Kentucky, New York, Ohio, Pennsylvania, and West Virginia

16. The approximate locations of the Ben Hur and Rose Hill oil fields, Lee County, Virginia, and the Swan Creek oil field, Hancock and Claiborne Counties, Tennessee. 


\section{Conversion Factors}

\begin{tabular}{lcl}
\hline \multicolumn{1}{c}{ Multiply } & By & \multicolumn{1}{c}{ To obtain } \\
\hline mile $(\mathrm{mi})$ & Length & \\
\hline & 1.609 & kilometer $(\mathrm{km})$ \\
\hline square mile $\left(\mathrm{mi}^{2}\right)$ & Area & \\
\hline & 2.590 & square kilometer $\left(\mathrm{km}^{2}\right)$ \\
\hline $\begin{array}{l}\text { pound } \\
\text { short ton }(2,000 \text { pounds } \\
\text { avoirdupois) }\end{array}$ & 0.4536 & $\begin{array}{l}\text { kilogram } \\
\text { metric ton }(\text { megagram }=1,000 \\
\text { kilograms })\end{array}$ \\
\hline $\begin{array}{l}\text { British thermal unit (Btu) } \\
\text { British thermal unit per pound } \\
\text { avoirdupois (Btu/lb) }\end{array}$ & 0.9072 & joule $(\mathrm{J})$ \\
\hline
\end{tabular}




\title{
Coal and Petroleum Resources in the Appalachian Basin- Index Maps of Included Studies
}

\author{
By Leslie F. Ruppert, ${ }^{1}$ Michael H. Trippi, ${ }^{1}$ and Scott Kinney ${ }^{2}$
}

\section{Introduction}

This chapter B.1 of U.S. Geological Survey (USGS) Professional Paper 1708 provides index maps for many of the studies described in other chapters of the report. Scientists of the USGS and State geological surveys studied coal and petroleum resources in the central and southern Appalachian structural basins. In the southern Appalachian basin, studies focused on the coal-bearing parts of the Black Warrior basin in Alabama. The scientists used new and existing geologic data sets to create a common spatial geologic framework for the fossil-fuel-bearing strata of the central Appalachian basin and the Black Warrior basin in Alabama.

Digital data have been compiled into a geographic information system (GIS) that is included in chapter I.1 (Trippi and others, this volume). Shape files and related metadata for features shown in the index maps of this chapter can be downloaded from chapter I.1.

The study area for the Appalachian basin resource framework study includes the fossil-fuel-bearing strata of the following States (listed alphabetically): Alabama, Kentucky, Maryland, New York, Ohio, Pennsylvania, Tennessee, Virginia, and West Virginia. The outline of the study area is shown in figure 1; it differs from the boundary of the Appalachian Basin Province (Province 67) defined for the 1995 National Oil and Gas Assessment (NOGA) by the U.S. Geological Survey (1996a). The difference is that the study area includes regions where the Pennsylvanian coal-bearing strata crop out but does not include all of the oil- and gas-bearing strata of the Black Warrior basin, Alabama.

The reasons for providing the index maps in this chapter are to show the locations of different studies, to give an overview of topics covered, and to help the user choose which chapter to read. Figures 1 and 2 show the study area outline and county names. Figure 3 shows oil and gas production in 1995 and 2005. Figure 4 shows locations of Upper Devonian sandstone oil and gas fields. Figure 5 shows major coal

${ }^{1}$ U.S. Geological Survey, Reston, Va.

${ }^{2}$ U.S. Geological Survey, Denver, Colo. regions and coal fields. Figure 6 shows coal production by county.

Figure 7 shows the locations of 10 cross sections of regional extent through the subsurface of the Appalachian basin. Figure 8 shows conodont alteration index sample locations and interpreted isograds for Ordovician rocks.

Figure 9 shows vitrinite-reflectance data for Pennsylvanian coal in the Appalachian basin. Figure 10 shows the locations of coalbed-methane (CBM) assessment units in the study area, and figure 12 shows counties producing CBM. Figure 12 shows sulfur content of coal delivered to powerplants from coal-producing counties in the Appalachian basin and Black Warrior basin.

Figure 13 shows locations of wells in Ohio and Pennsylvania where oil and gas were sampled in Lower Silurian reservoirs. Figure 14 shows the Conasauga-Rome/Conasauga Total Petroleum System and selected wells in the Rome trough in Kentucky and West Virginia having oil and gas production and shows. Figure 15 shows the locations of samples from Silurian reservoirs in Kentucky, New York, Ohio, Pennsylvania, and West Virginia; the samples yielded total organic carbon data. Figure 16 shows the locations of the Ben Hur and Rose Hill oil fields, Virginia, and the Swan Creek oil field, Tennessee.

The one index map that is not shown is the areal extent of the shale gas plays in the basin. The extents of the plays can be found in Coleman and others (this volume, chap. G.13).

\section{References Cited}

Arkle, Thomas, Jr., 1974, Stratigraphy of the Pennsylvanian and Permian Systems of the central Appalachians, in Briggs, Garrett, ed., Carboniferous of the Southeastern United States: Geological Society of America Special Paper 148, p. 5-29.

Attanasi, E.D., and Milici, R.C., 1998, Appalachian basin bituminous coal; Weight percent sulfur of produced coal by county, as received at the power plant: U.S. Geological Survey Open-File Report 98-763, 1 sheet. (Also available online at http://pubs.usgs.gov/of/1998/of98-763/.) (Digital compilation by W.C. Kallander and W.G. Wallace.) 
Dolton, G.L., Varnes, K.L., Gautier, D.L., and Barnett, D.L., 1995, Oil and gas resources assessment areas, 1995, lower 48 States: U.S. Geological Survey Open-File Report 95-75-I, 1 sheet, scale 1:5,000,000.

Harris, A.G., Harris, L.D., and Epstein, J.B., 1978, Oil and gas data from Paleozoic rocks in the Appalachian basin; Maps for assessing hydrocarbon potential and thermal maturity (conodont color alteration isograds and overburden isopachs): U.S. Geological Survey Miscellaneous Investigations Series Map I-917-E, 4 sheets.

Hatch, J.R., and Pawlewicz, M.J., comps., 2007, Geologic assessment of undiscovered oil and gas resources of the Black Warrior Basin Province, Alabama and Mississippi: U.S. Geological Survey Digital Data Series DDS-69-I, ReadMe file, 5 chapters, and spatial data on 1 CD-ROM. (Also available online at http://pubs.usgs.gov/dds/dds-069/ dds-069-i/.) (Report was compiled from work of the U.S. Geological Survey Black Warrior Basin Province Assessment Team.)

Hatch, J.R., Pawlewicz, M.J., Charpentier, R.R., Cook, T.A., Crovelli, R.A., Klett, T.R., Pollastro, R.M., and Schenk, C.J. (all of the U.S. Geological Survey Black Warrior Basin Province Assessment Team), 2003, Assessment of undiscovered oil and gas resources of the Black Warrior Basin Province, 2002: U.S. Geological Survey Fact Sheet FS-038-03, 2 p. (Also available online at http://pubs.usgs. gov/fs/fs-038-03/.)

IHS Energy Group, 2003 and 2007, PI/Dwights Plus US well data. (Database available from IHS Energy Group, 15 Inverness Way East, Englewood, CO, 80112, U.S.A.)

Mast, R.F., Root, D.H., Williams, L.P., Beeman, W.R., and Barnett, D.L., 1998, Areas of historical oil and gas exploration and production in the conterminous United States: U.S. Geological Survey Geologic Investigations Series Map I-2582, 1 sheet, scale 1:3,750,000.

Milici, R.C., 1974, Stratigraphy and depositional environments of Upper Mississippian and Lower Pennsylvanian rocks in the southern Cumberland Plateau of Tennessee, in Briggs, Garrett, ed., Carboniferous of the Southeastern United States: Geological Society of America Special Paper 148, p. 115-133.
Milici, R.C., 1999, Bituminous coal production in the Appalachian basin; Past, present, and future: U.S. Geological Survey Miscellaneous Field Studies Map MF-2330, 4 sheets, available online at http://pubs.usgs.gov/mf-maps/mf-2330/. (Digital compilation by W.C. Kallander, W.G. Wallace, and E.A. Morrissey.) (Superseded by USGS Professional Paper 1708-D.3, in this volume.)

Milici, R.C., 2002, Coalbed methane production in the Appalachian basin: U.S. Geological Survey Open-File Report 02-105, unpaginated, available online at http://pubs.usgs. gov/of/2002/of02-105/. (Superseded by USGS Professional Paper 1708-G.2, in this volume.)

Milici, R.C., 2004, Assessment of Appalachian basin oil and gas resources; Carboniferous Coal-bed Gas Total Petroleum System: U.S. Geological Survey Open-File Report 20041272, 98 p., available only online at http://pubs.usgs.gov/ of/2004/1272/. (Superseded by USGS Professional Paper 1708-G.1, in this volume.)

Milici, R.C., and Hatch, J.R., 2004, Assessment of undiscovered Carboniferous coal-bed gas resources of the Appalachian Basin and Black Warrior Basin Provinces, 2002: U.S. Geological Survey Fact Sheet 2004-3092, 2 p. (Also available online at http://pubs.usgs.gov/fs/2004/3092/.)

Milici, R.C., Ryder, R.T., Swezey, C.S., Charpentier, R.R., Cook, T.A., Crovelli, R.A., Klett, T.R., Pollastro, R.M., and Schenk, C.J. (all of the U.S. Geological Survey Appalachian Basin Province Assessment Team), 2003, Assessment of undiscovered oil and gas resources of the Appalachian Basin Province, 2002: U.S. Geological Survey Fact Sheet FS-009-03, 2 p. (Also available online at http://pubs.usgs. gov/fs/fs-009-03/.)

U.S. Geological Survey, 1996a, [1995] National Oil and Gas Assessment: U.S. Geological Survey Web site accessed February 8, 2007, at http://energy.cr.usgs.gov/oilgas/noga/ index.html.

U.S. Geological Survey, 1996b, 1995 National Oil and Gas Assessment - One-quarter mile cell data: U.S. Geological Survey data accessed online February 8, 2007, at http:// energy.cr.usgs.gov/oilgas/noga/data.html. 
Figures 1-16 


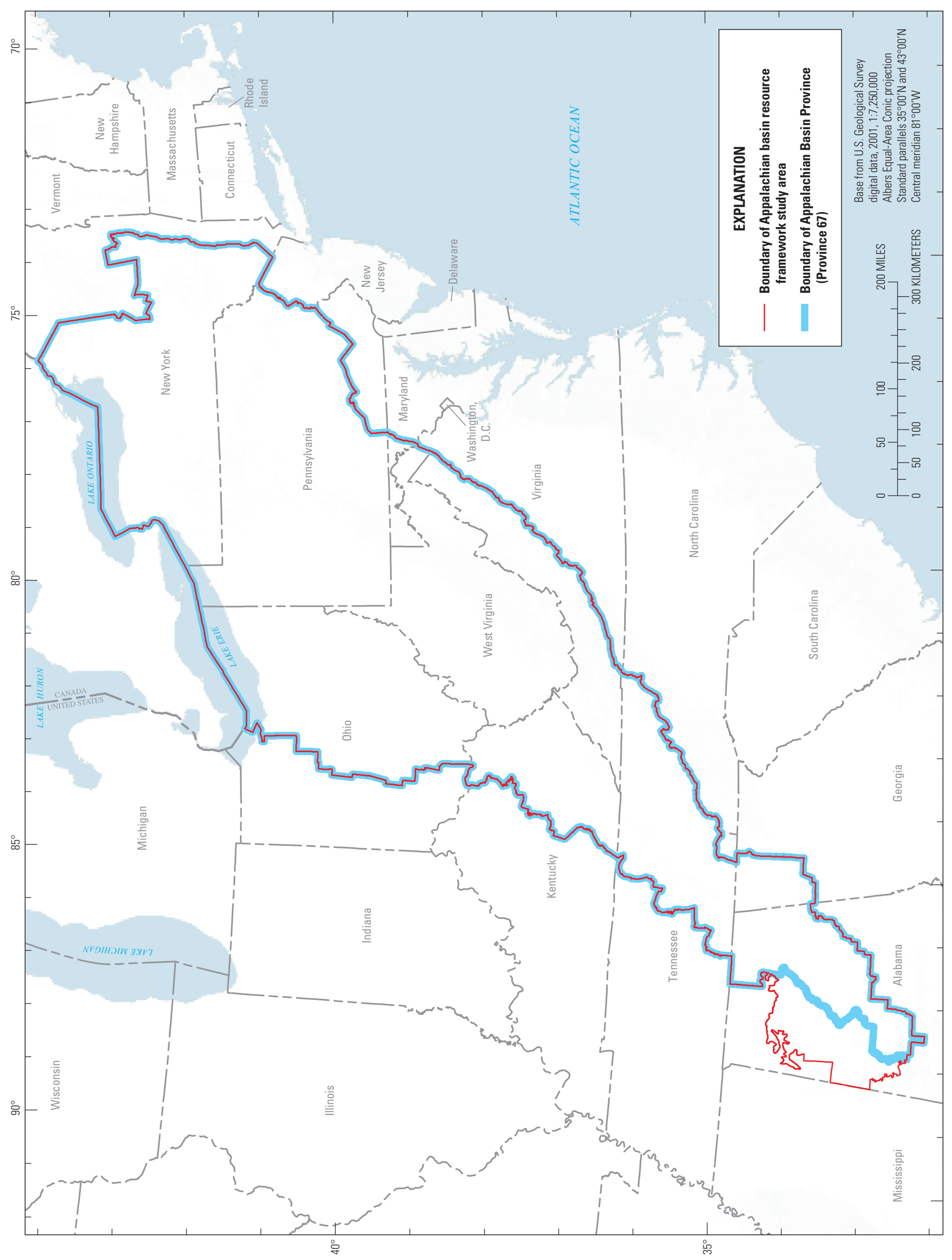



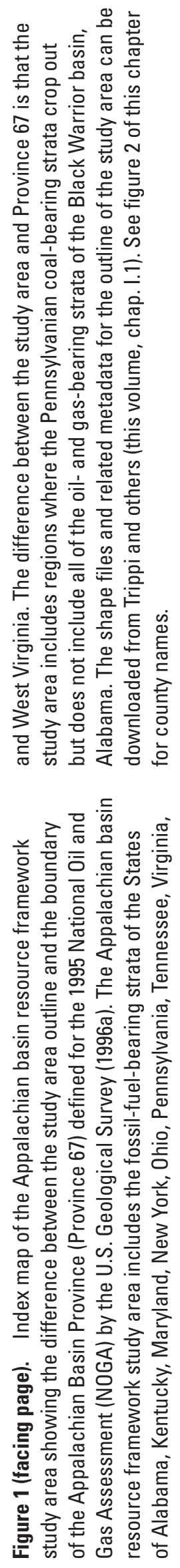


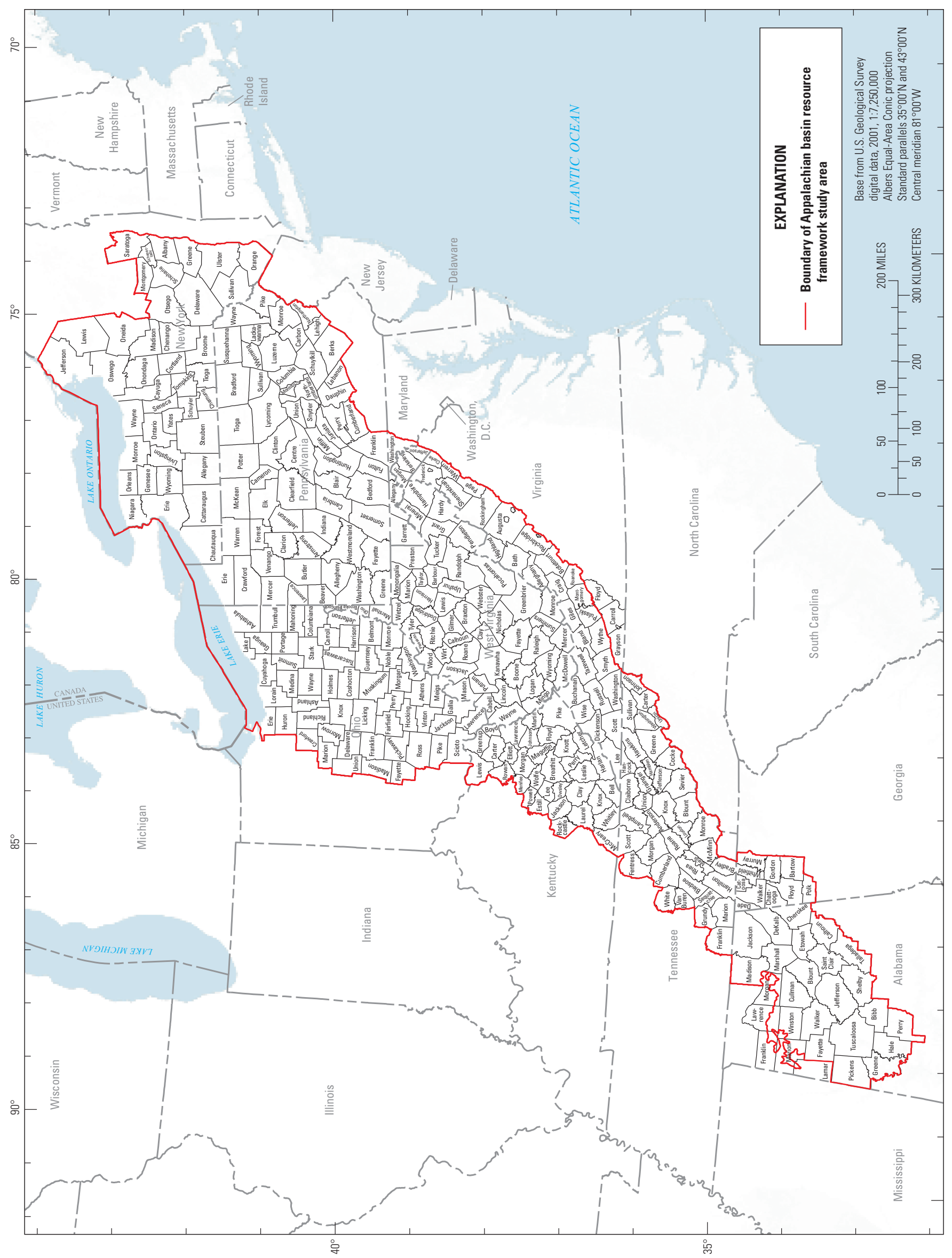




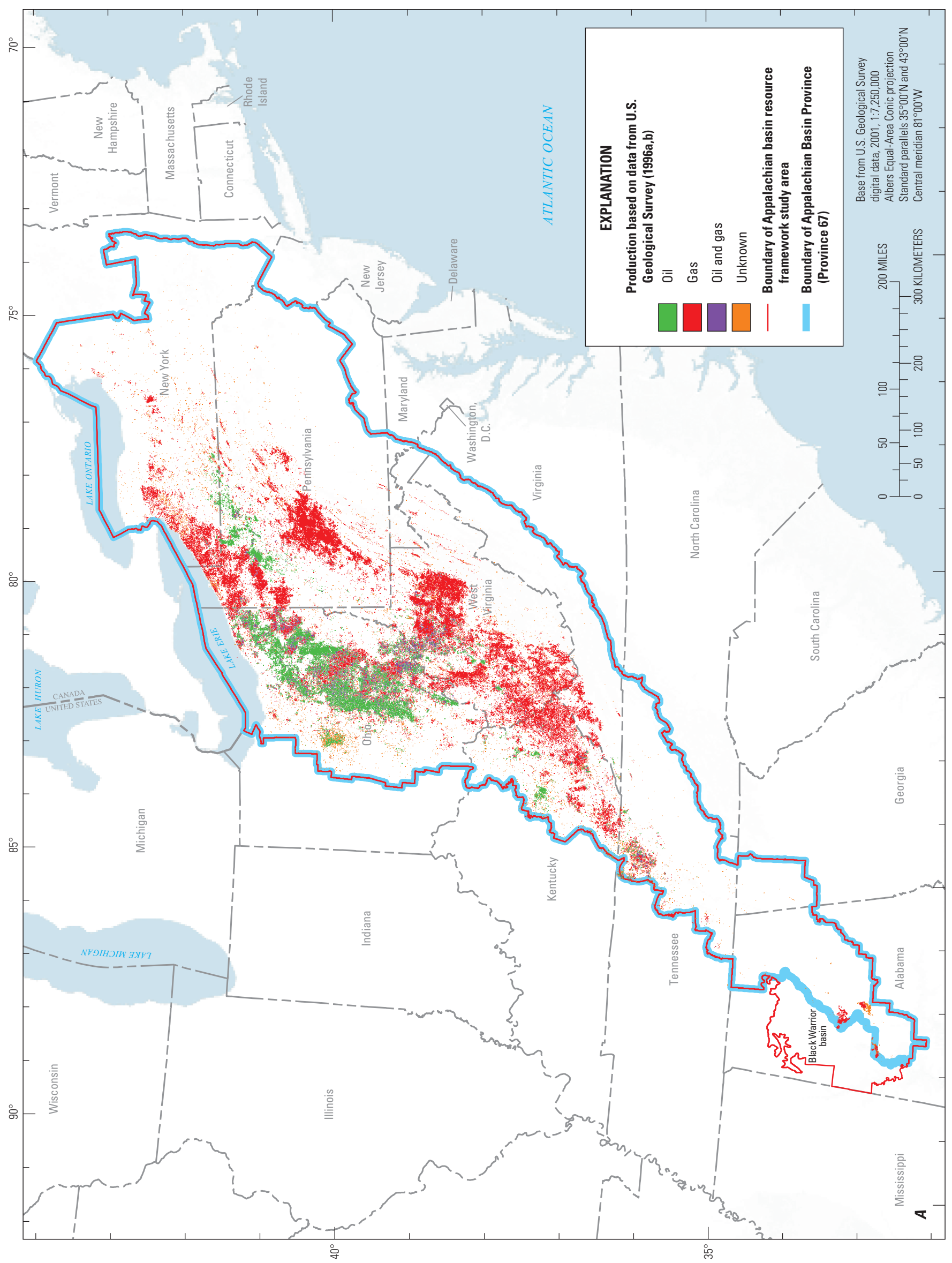



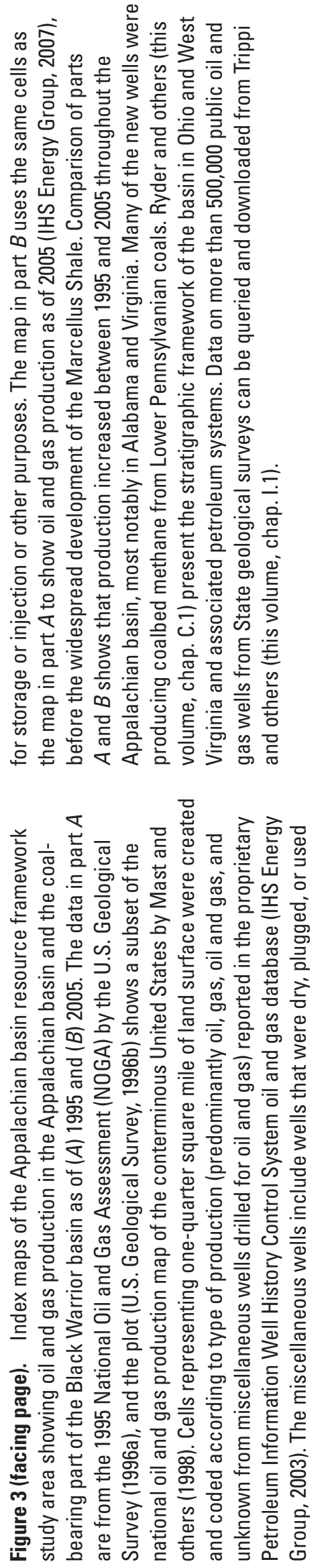


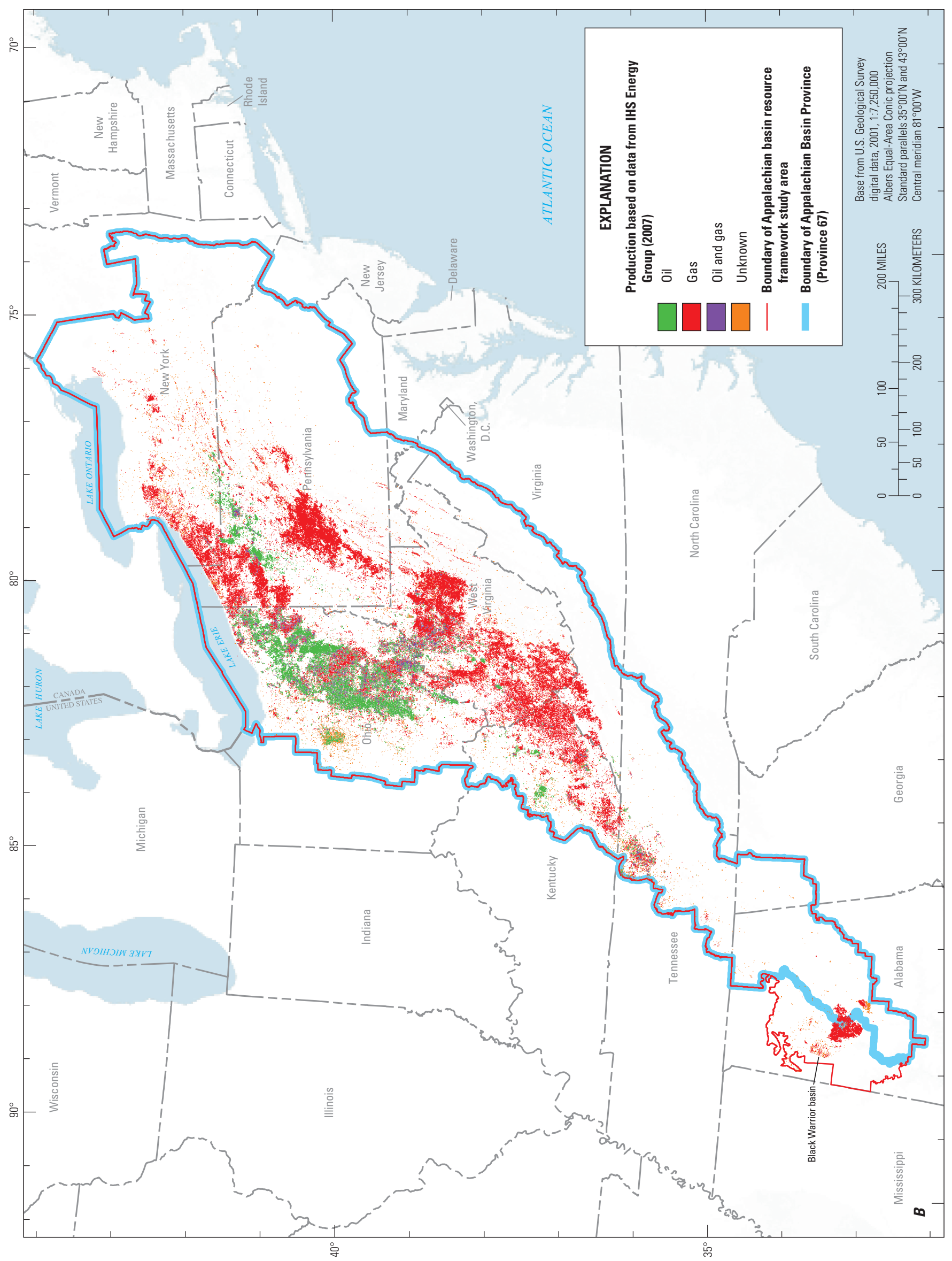




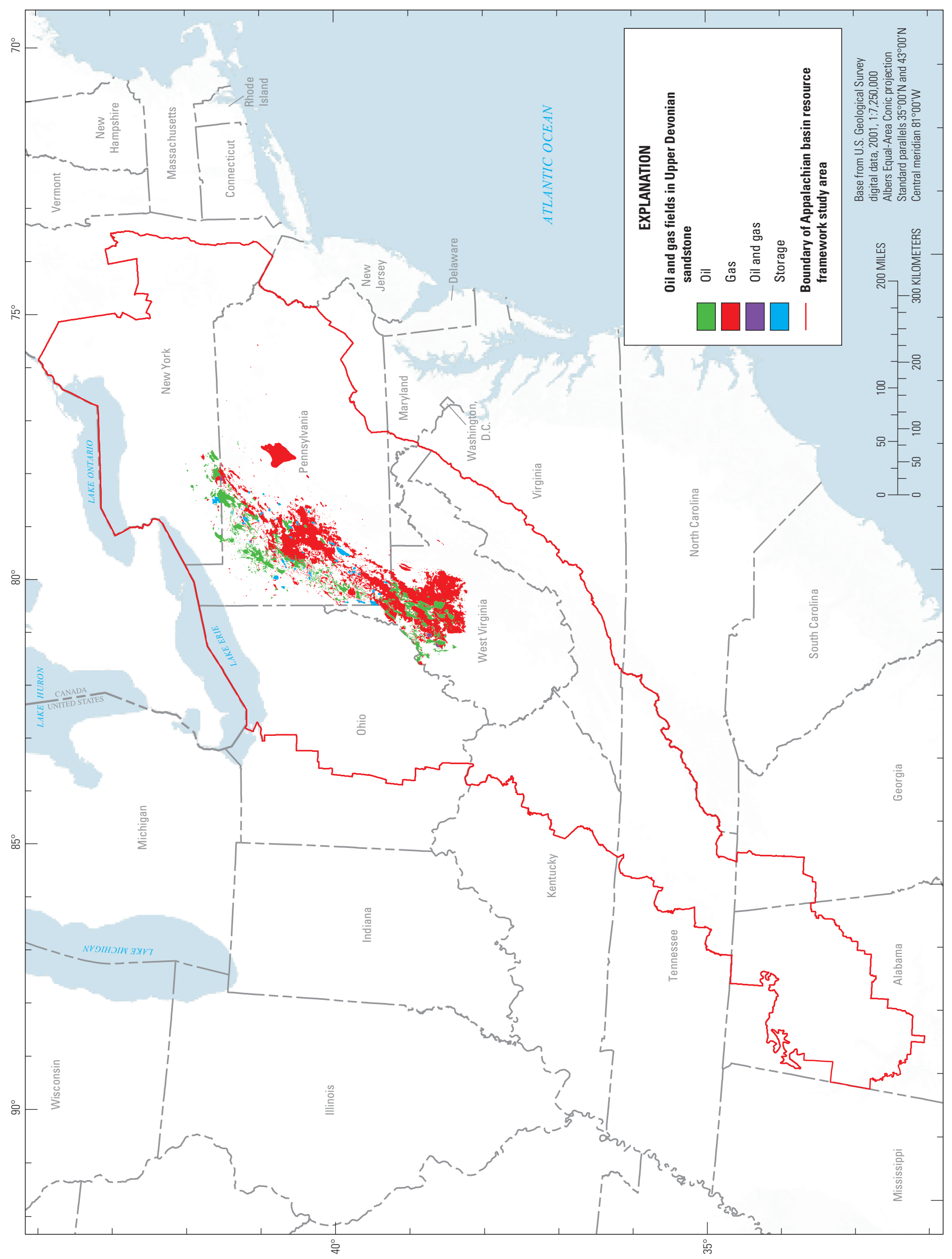



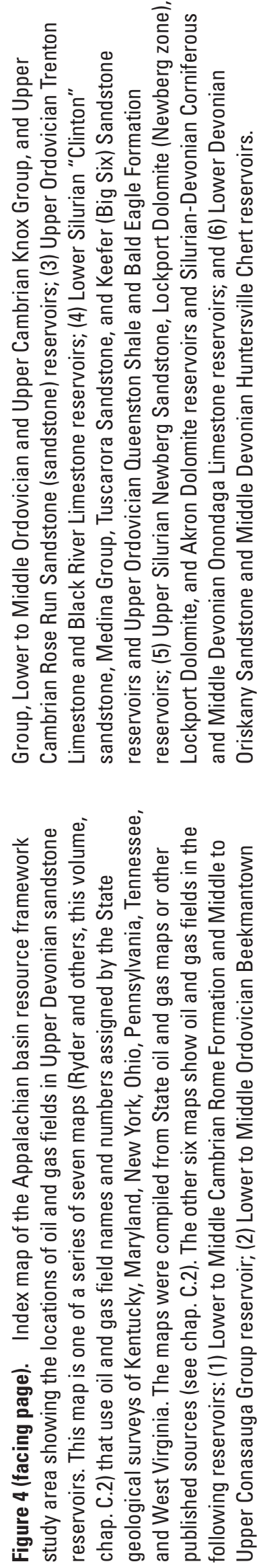


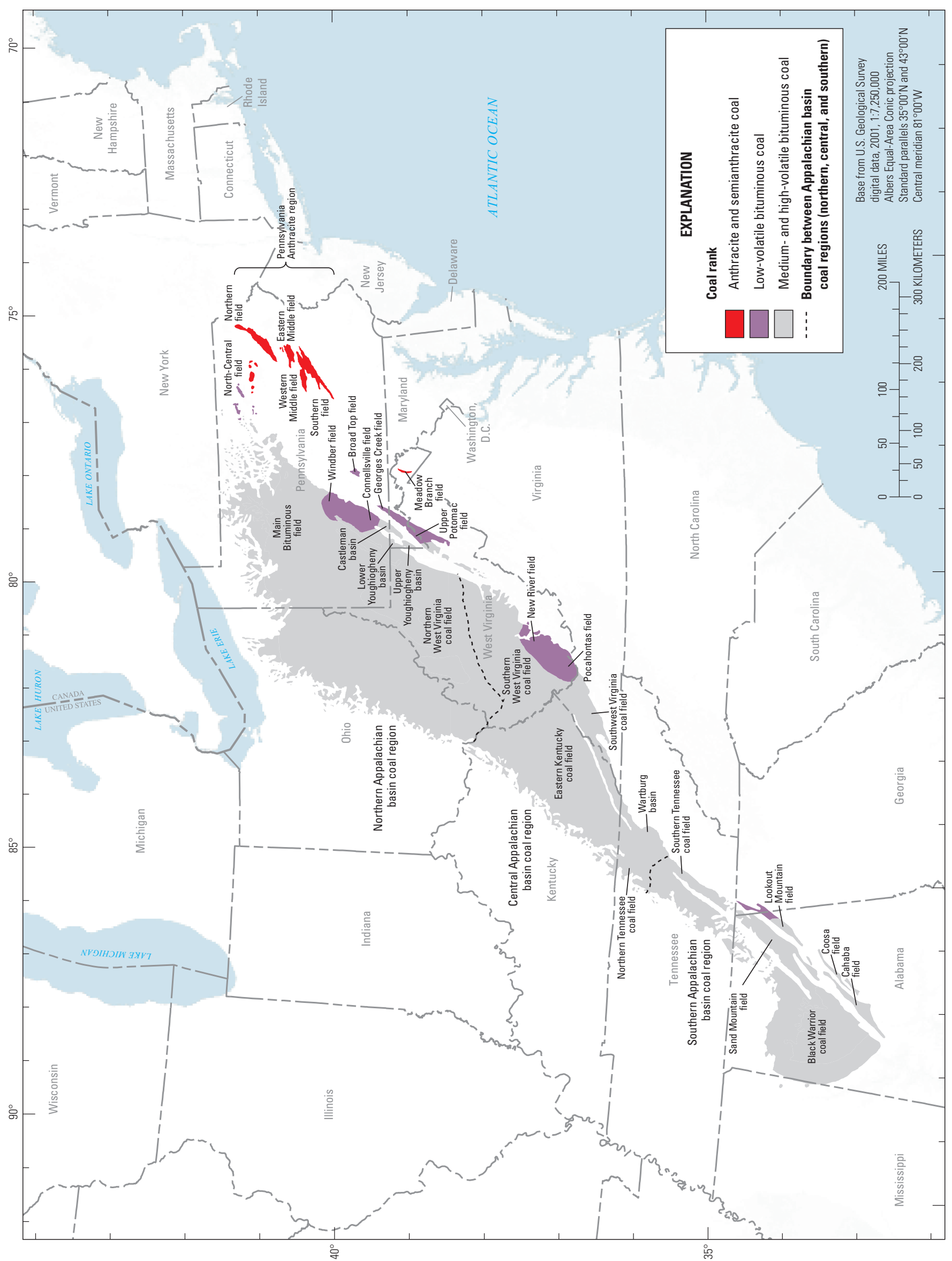



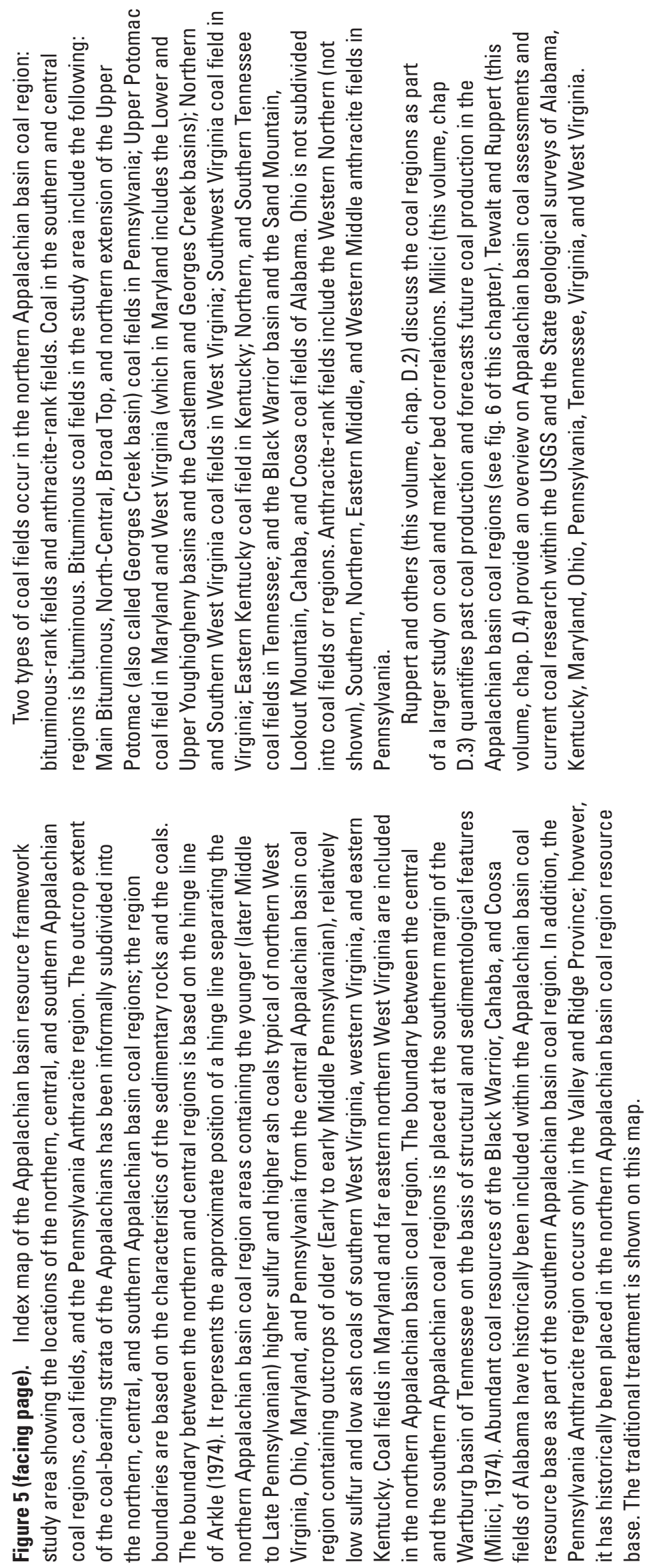


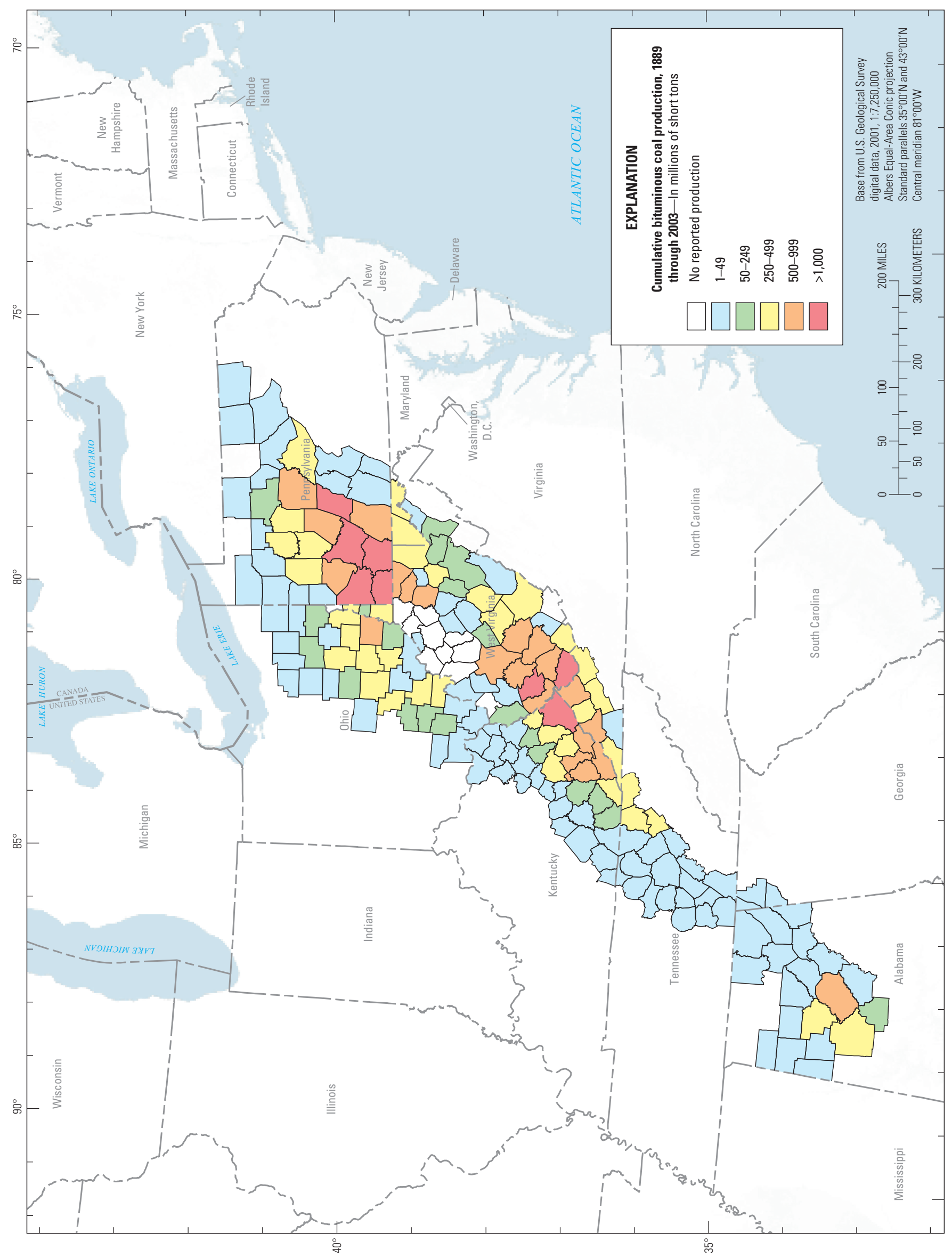



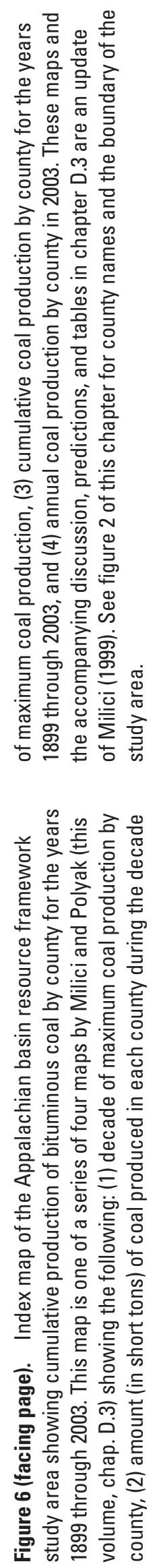


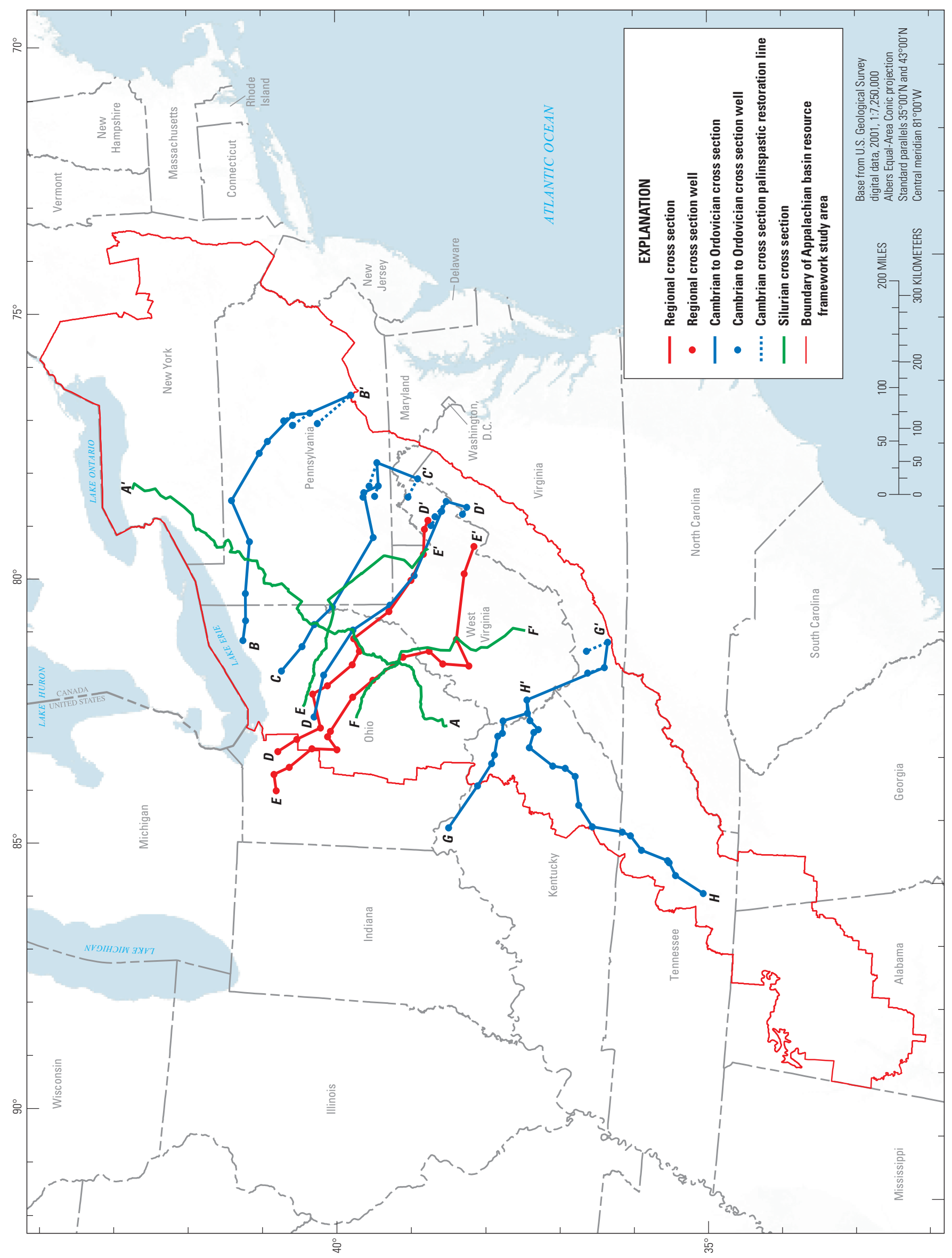



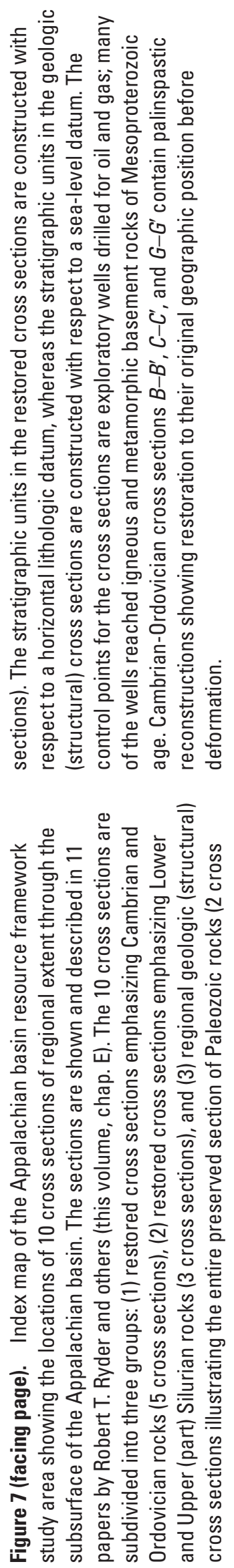


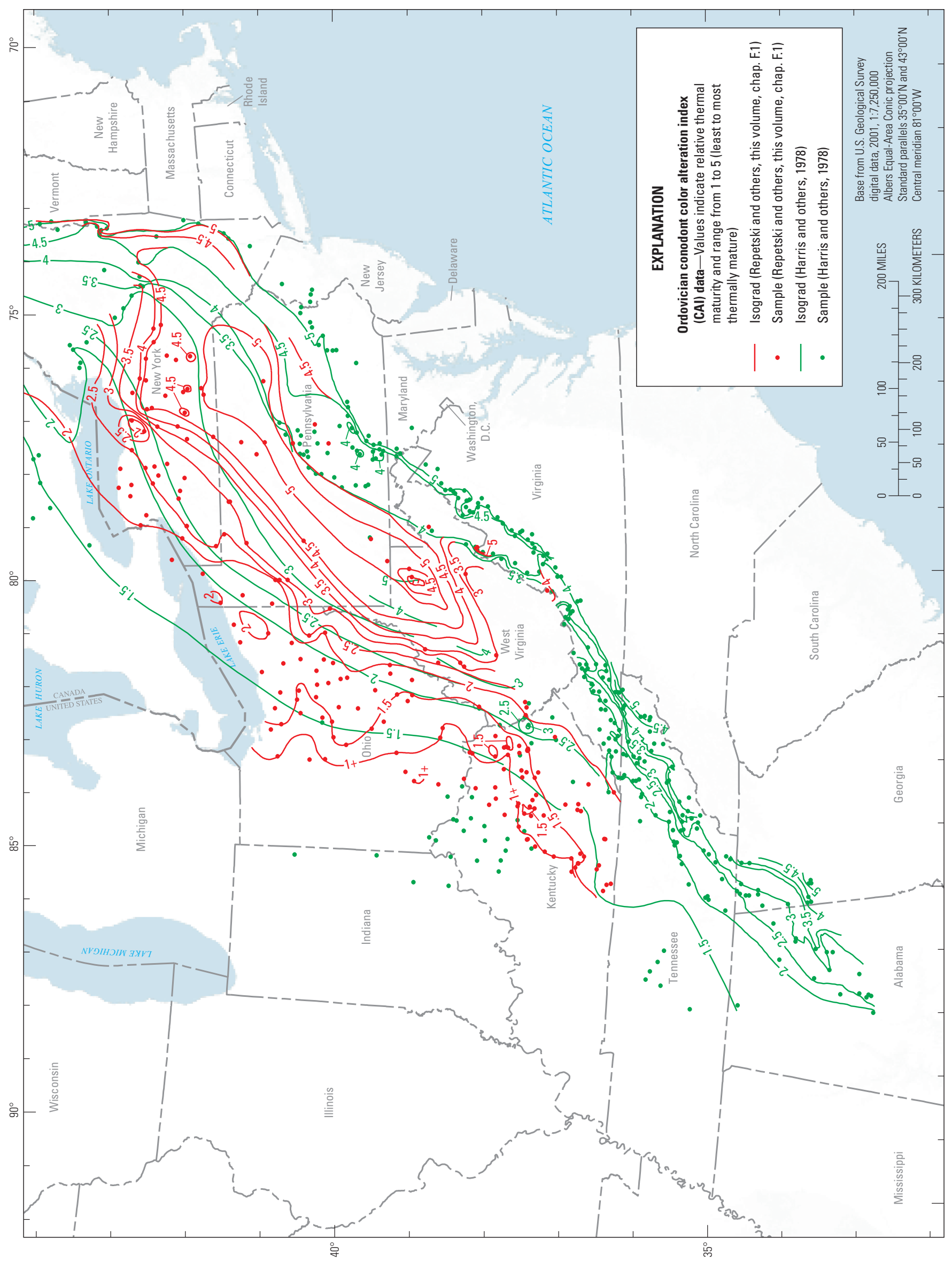



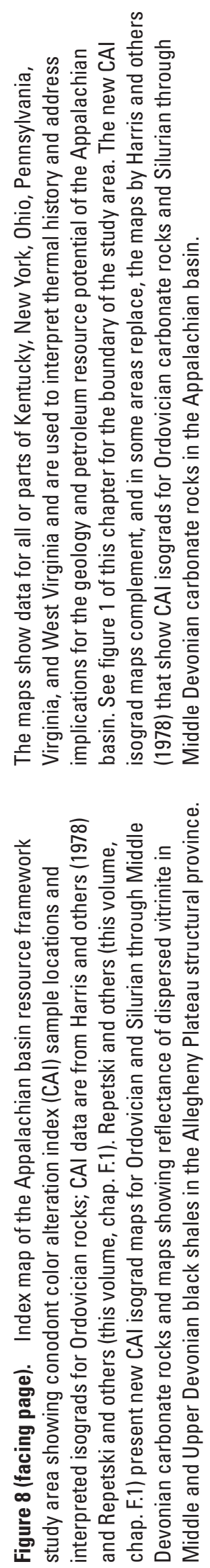


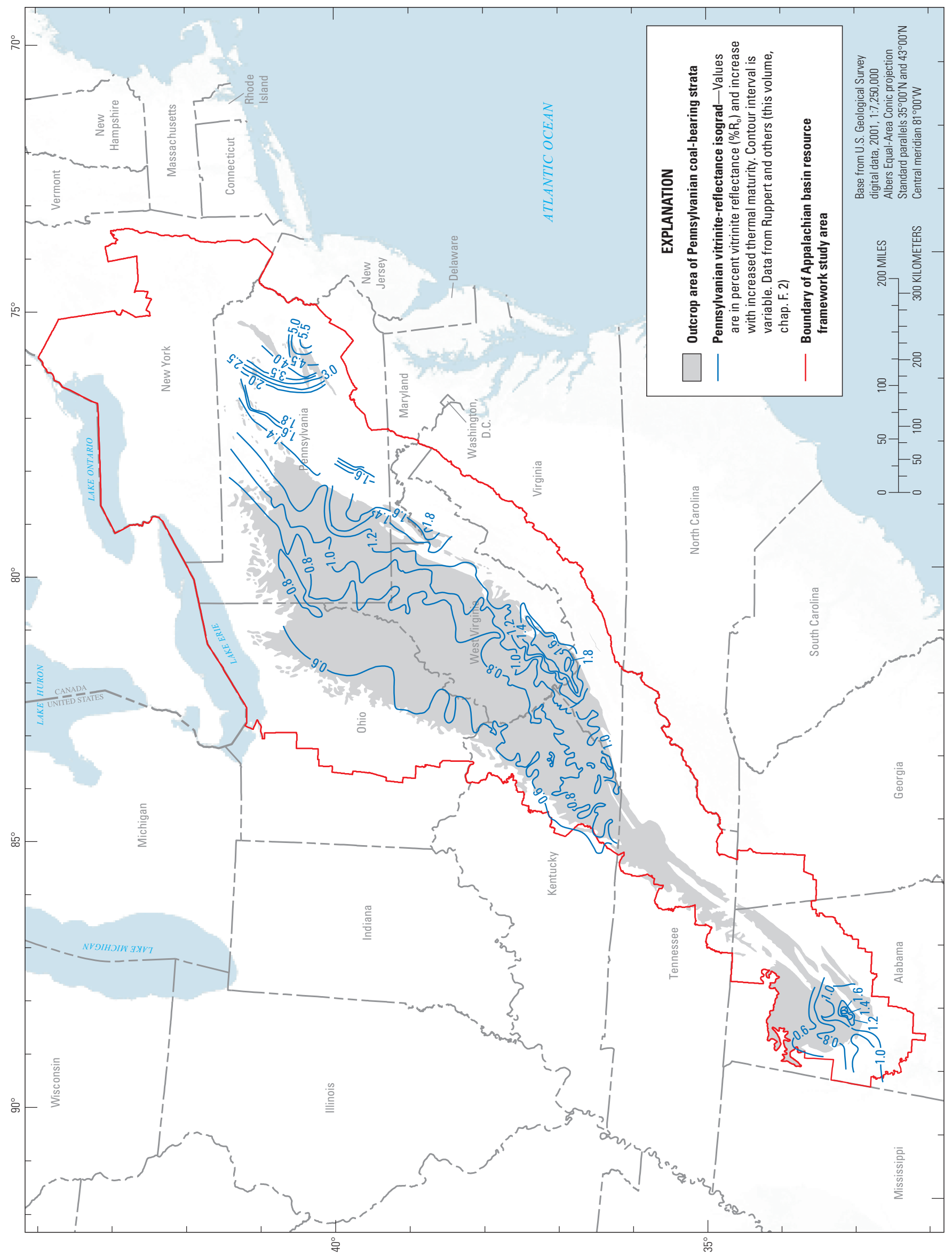



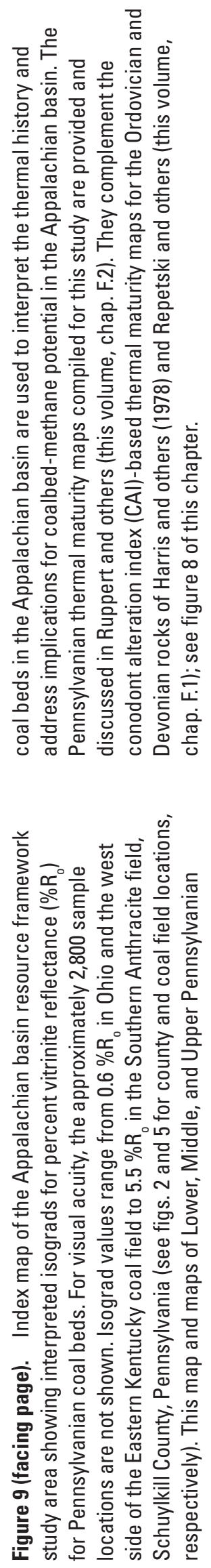


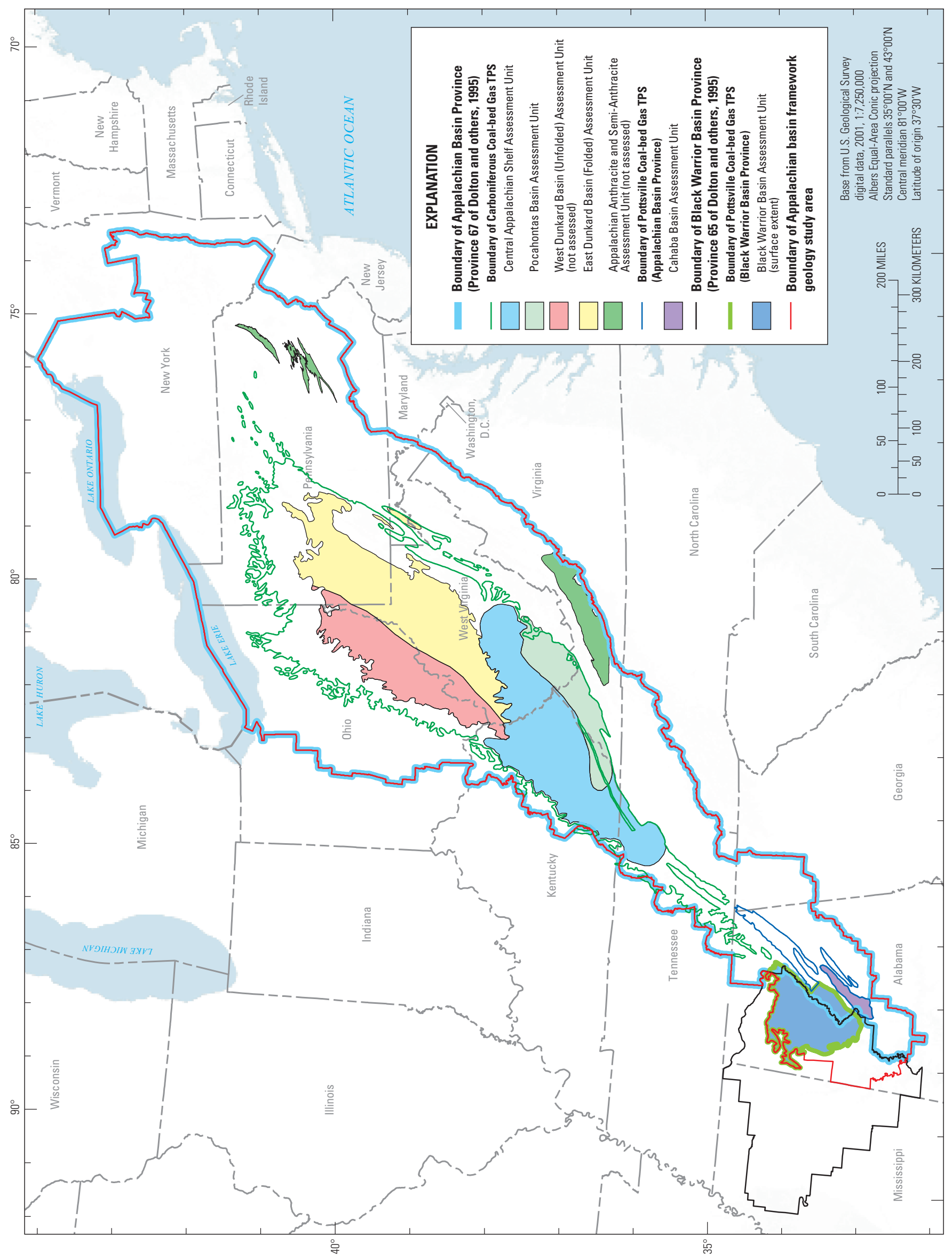



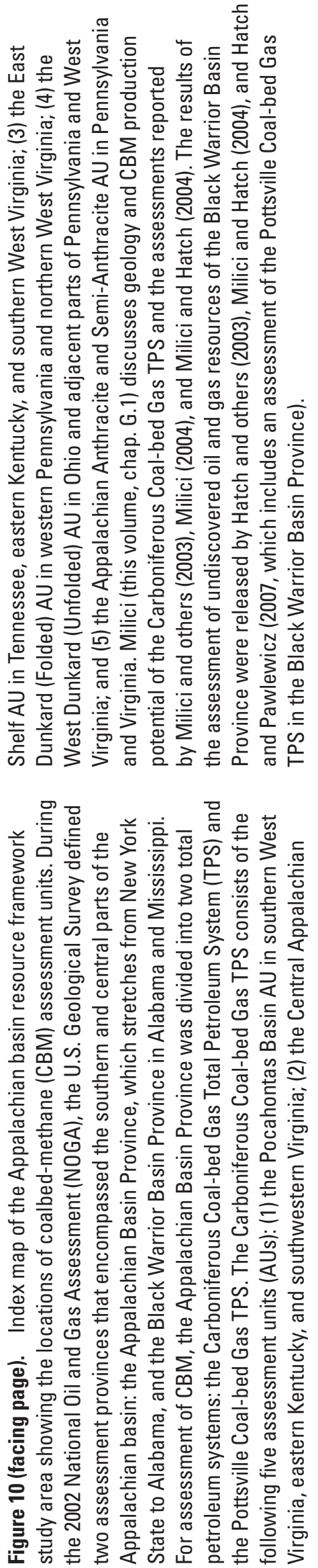


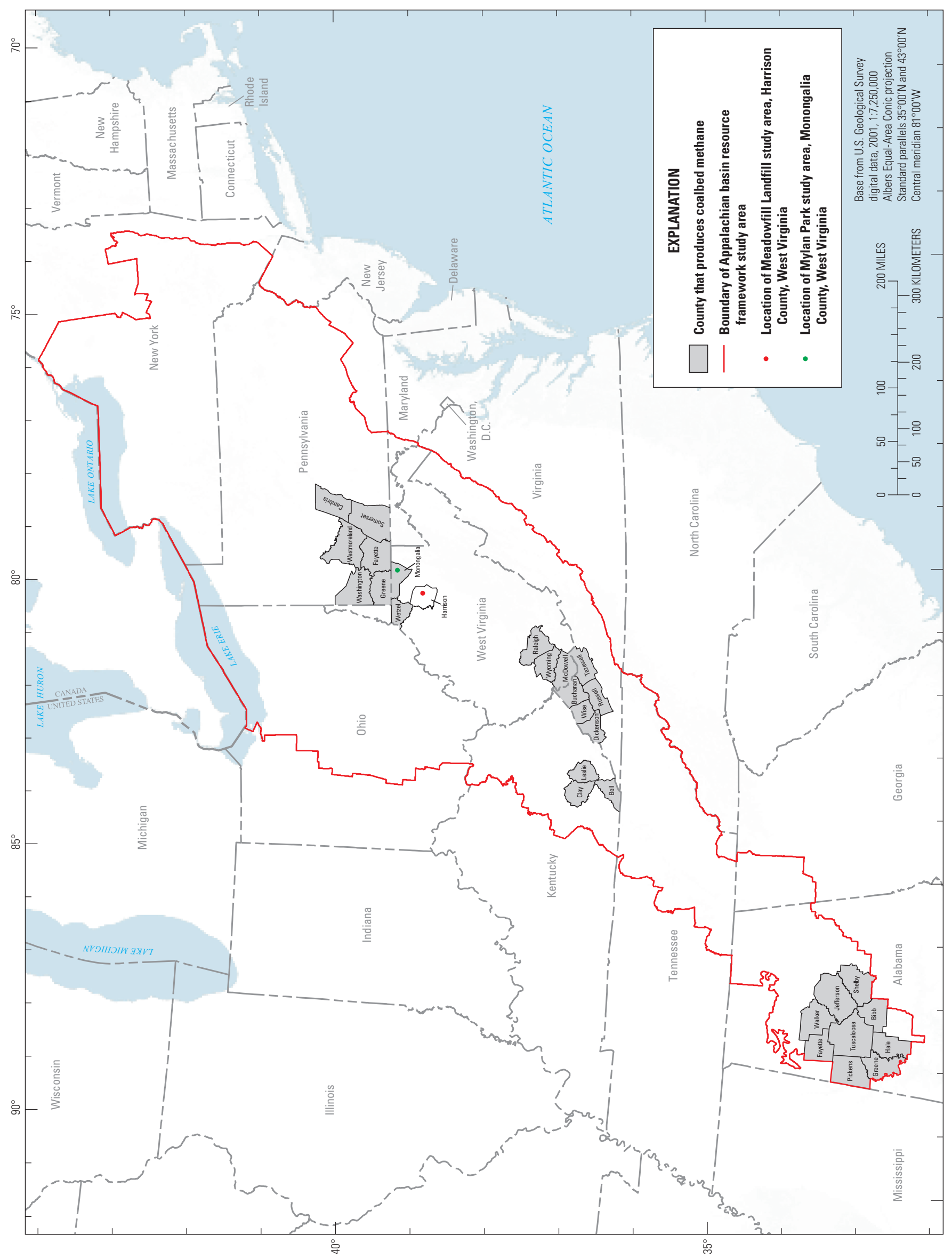



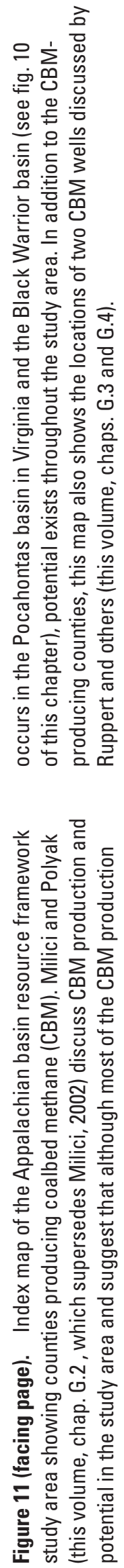


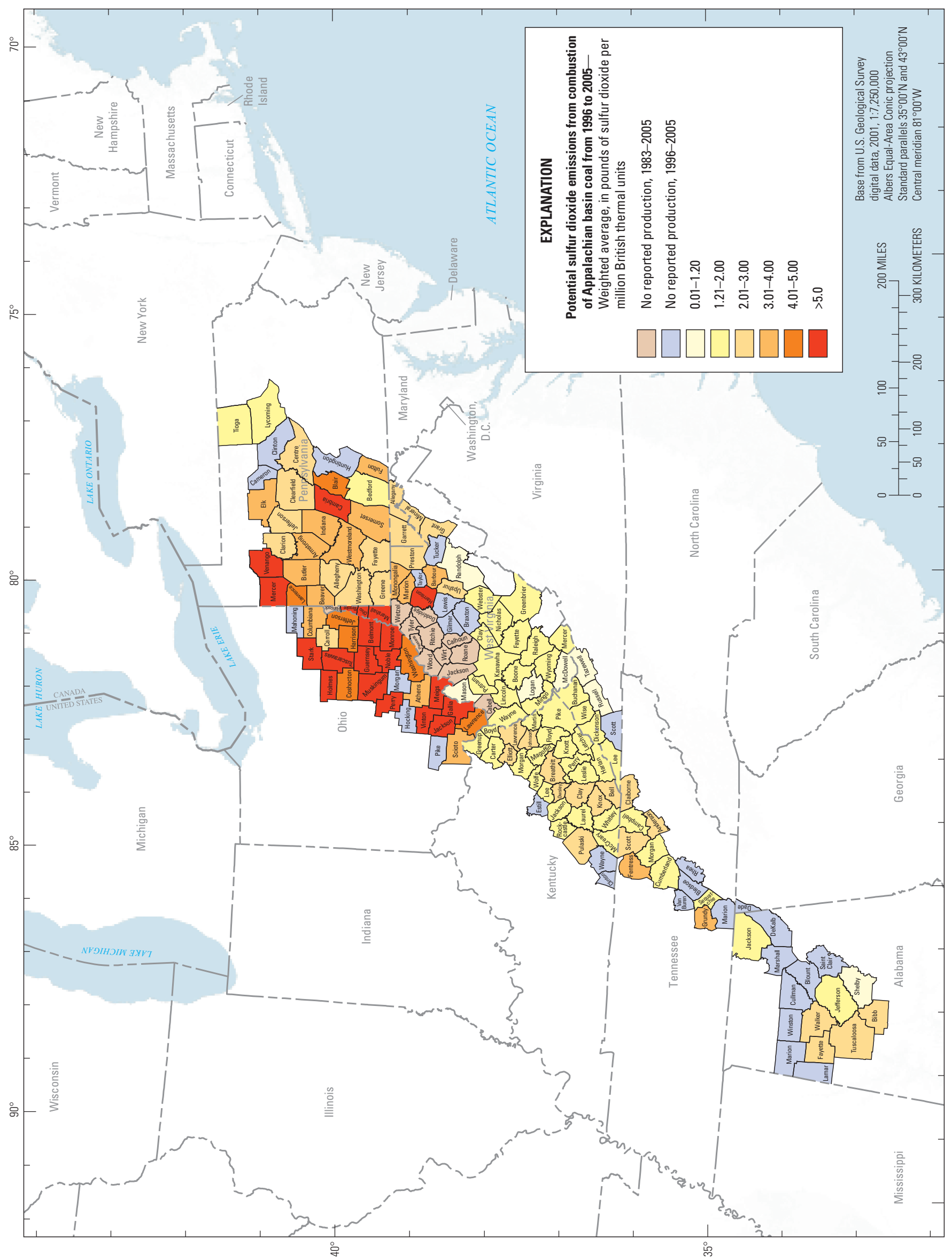



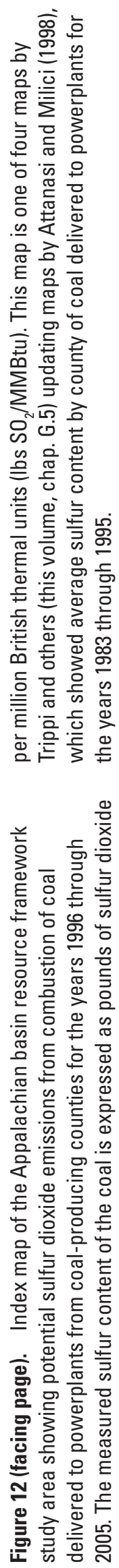


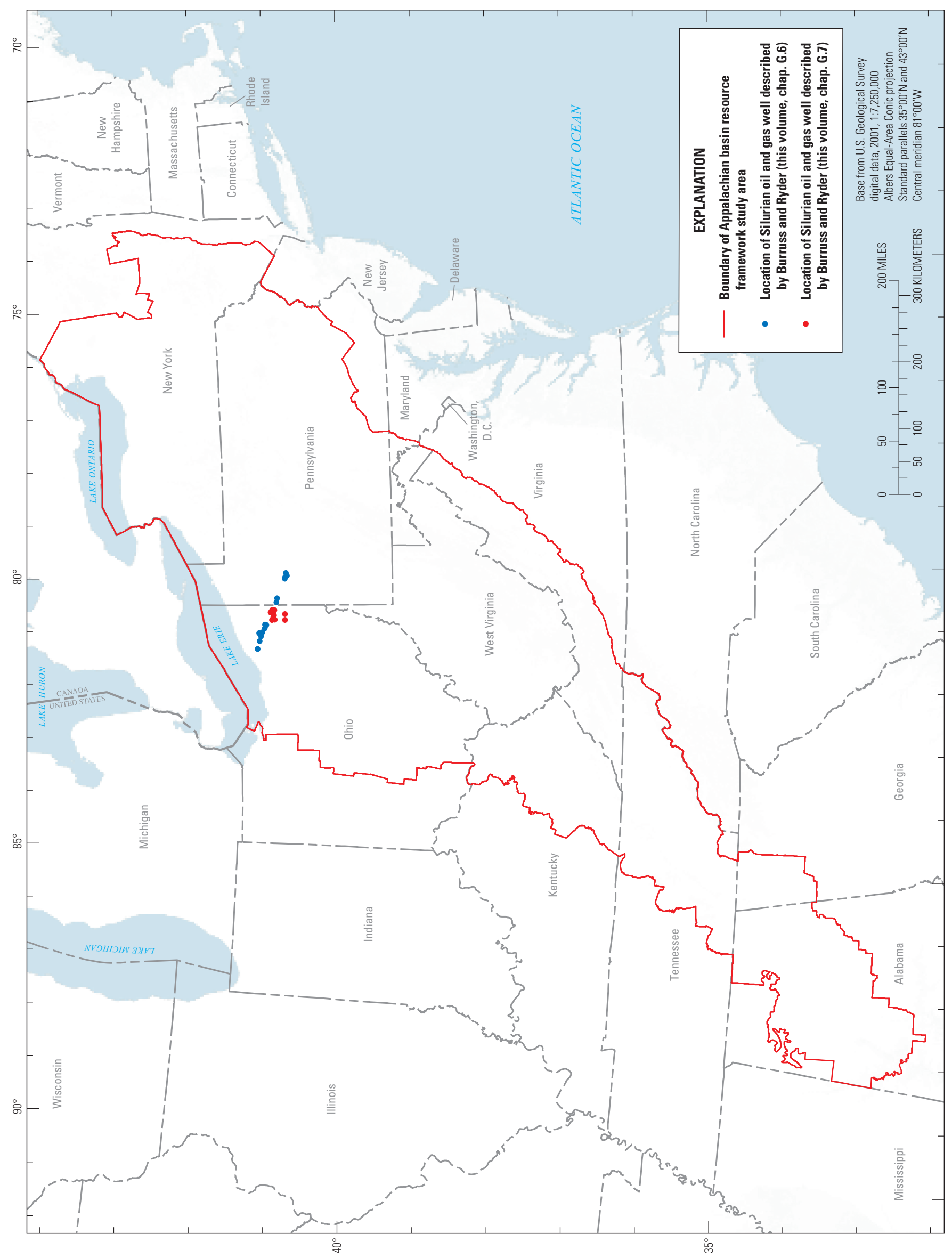



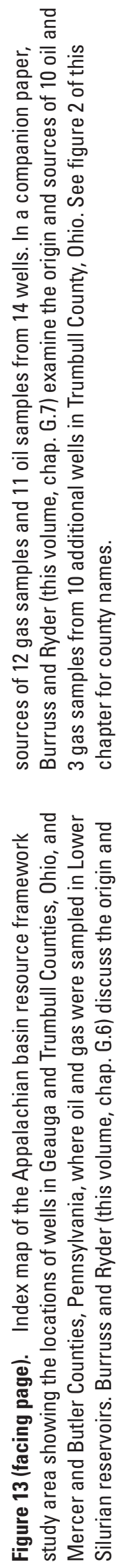


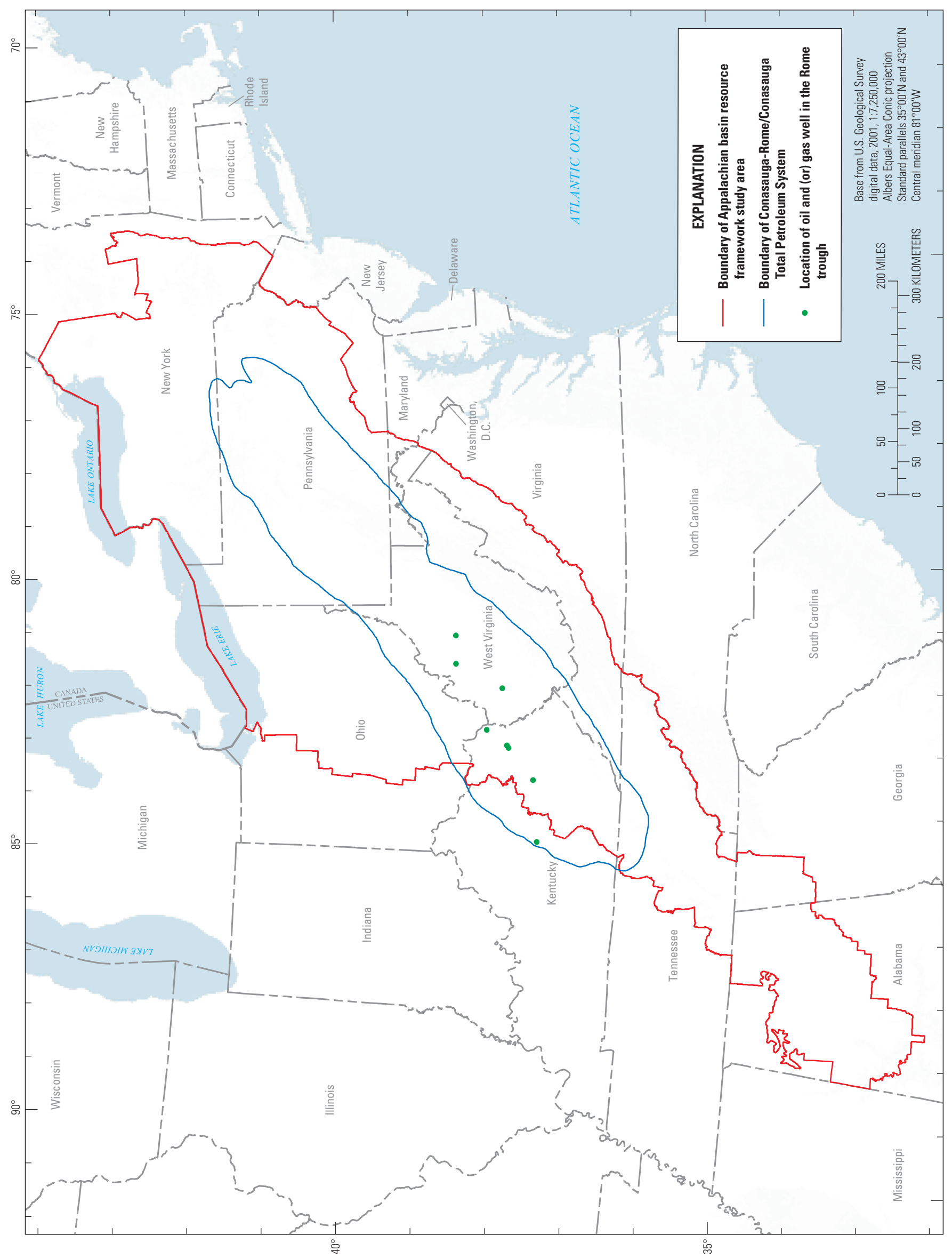



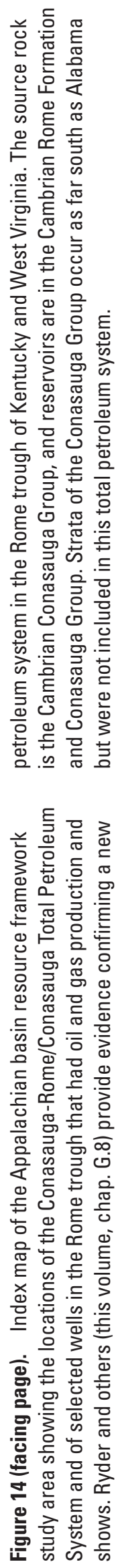


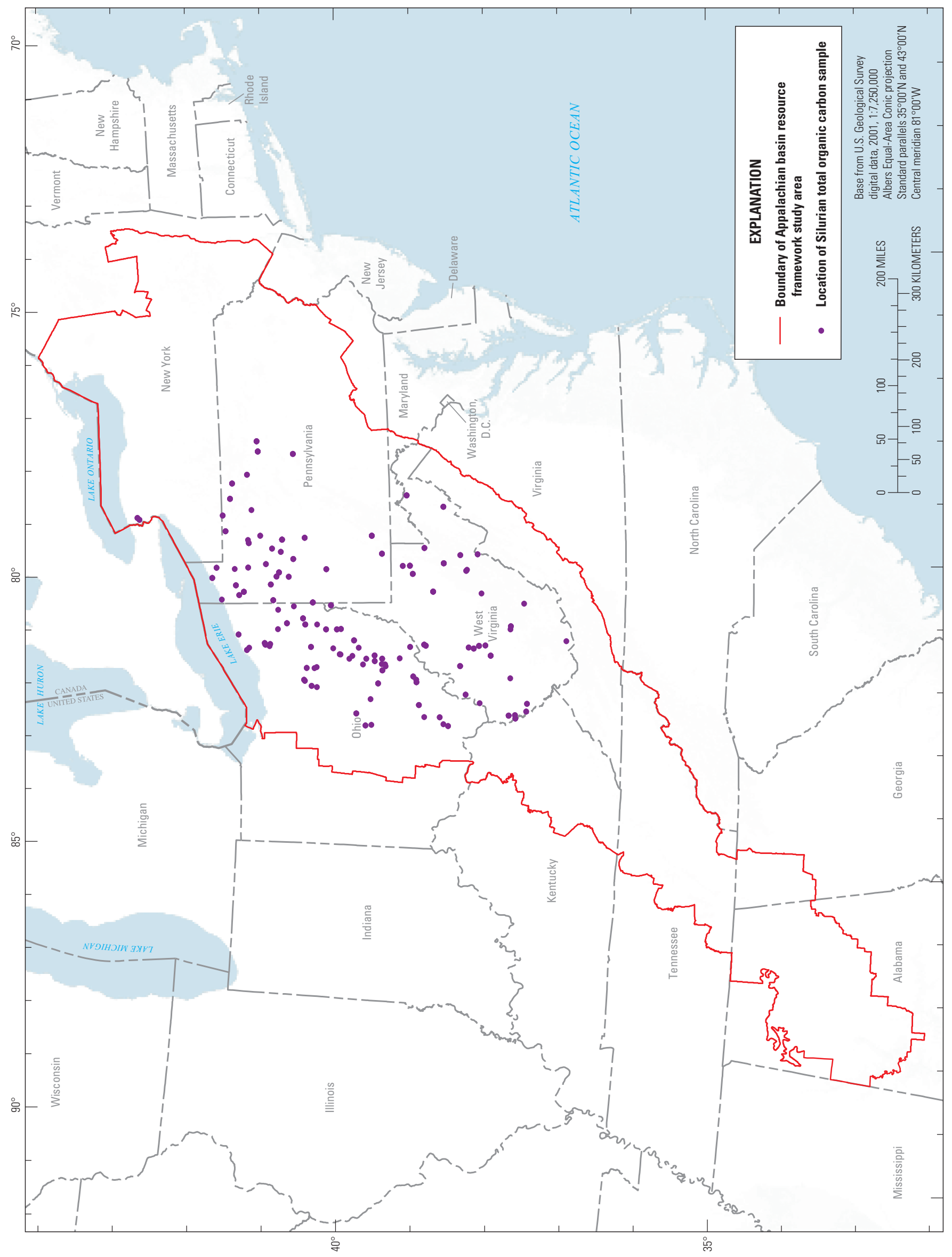



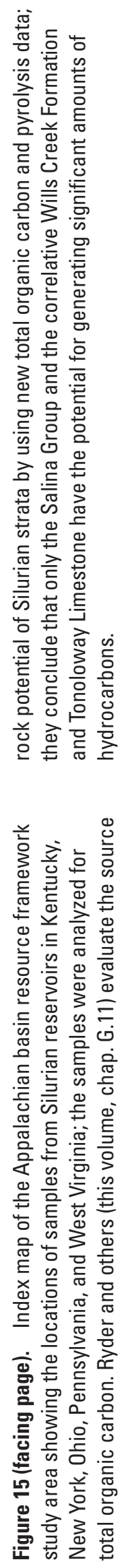


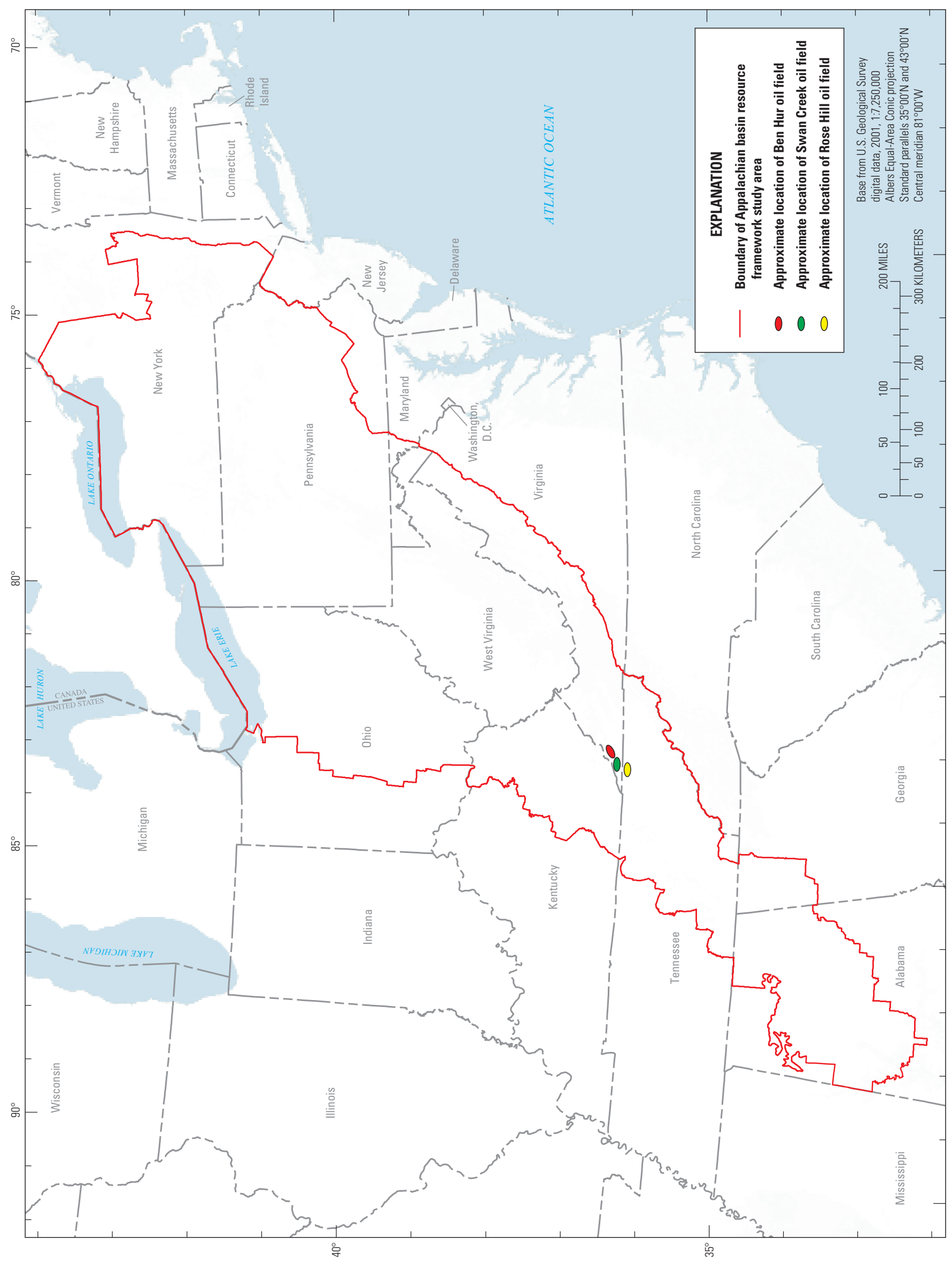



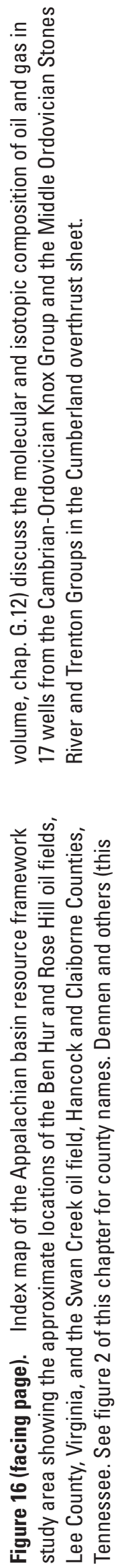